\title{
Suburbanisation and Suburbanisms
}

\author{
Heiderose Kilper ${ }^{1}$ \\ Published online: 3 April 2018 \\ (c) Springer-Verlag GmbH Deutschland, ein Teil von Springer Nature 2018
}

The second half of the twentieth century in particular is viewed as a period of suburbanisation: the movement of the resident population from the inner cities and agglomerations into the surrounding areas. For a long time the notion that the process of suburbanisation was leading to the death of the inner city was widely spread in urban research. The decay of parts of the (industrialised) inner cities in the USA from the second half of the twentieth century provided empirical evidence supporting this point of view, as did findings showing quantitative losses of population and jobs in Western European agglomerations in the 1980s and 1990s. This special issue of the journal 'Raumforschung und Raumordnung I Spatial Research and Planning' is dedicated to the topic of 'Suburbanisation and Suburbanisms' and aims to direct attention to the fact that, despite the popular discourse about reurbanisation and gentrification, developmental pressure on suburban spaces continues. The focus of interest is on suburbanisation processes in Europe. The papers in this special issue discuss empirical analyses of developments in German, Swiss and French urban regions. They demonstrate the spatial and temporal variety of current suburbanisation processes, indicating that this has a great deal to do with changes in lifestyles and ways of life and that it leads to the emergence of new forms of sociospatial differentiation.

In their introductory paper, Markus Hesse and Stefan Siedentop use a profound analysis of research literature about European suburbia and suburbanisation processes to unveil the transformations that both have undergone in the recent past. They discover a relatively wide range of suburban developments in Europe, based on consideration of factors such as the economic significance of suburban areas, living in the inner city and in suburbia, lifecycle changes of suburban areas, and strategies for suburban renewal. Noting the increasing diversity, consolidation and complexity

Prof. Dr. Heiderose Kilper

heiderose.kilper@leibniz-irs.de

1 Leibniz-Institut für raumbezogene Sozialforschung, Flakenstraße 29-31, 15537 Erkner, Germany of suburbia, they formulate implications for research and practice.

The empirical basis of the paper by Constance Carr and Evan McDonough is a case study on the Glattal valley in Switzerland, a region with no fixed territorial borders that stretches to the north and north-east of the city of Zürich, embracing numerous small municipalities. The authors show that today this suburban region not only attracts high-income households but also offers attractive jobs for commuters to the area. The region is increasingly positioning itself as a post-suburban growth region on the global market and even competes with the city of Zürich. The authors suggest that the driving force behind these developments is a specific pattern of inter-municipal and integrative planning and (locally) specific and path-dependent governance forms and land-use regulations.

In her paper Susanne Frank shows that suburbanisation processes influence not only developments in the areas surrounding cities but increasingly also impact on inner-urban districts. She uses the term 'inner-city suburbanisation' to refer to the phenomenon of the rapid emergence and spread of new, inner-city residential areas, which she names 'new family islands'. Based on empirical research on urban developments in Germany, particularly in Berlin and Dortmund, she formulates the hypothesis that the emergence of so-called inner-city middle-class family enclaves is a significant characteristic of current urban transformation in Germany.

The term peri-urbanisation is understood as referring to the built and socio-economic transformation of districts of rural character located at some geographic distance from cities. In their paper Mohamed Hilal, Sophie Legras and Jean Cavailhès investigate such districts, consulting population and employment trends in 230 French urban regions over the last 50 years as an empirical basis. Two findings are particularly noteworthy: the peri-urban development patterns of all large and medium-sized cities in France show many similarities; these developments are driven not only by the housing market but equally by locational decisions made by firms and the related job opportunities. 
Markus Hesse, Jan Polivka and Christa Reicher see the concept of suburban lifecycles as the key to a new understanding of suburbanisation. Analyses of findings from the continuous spatial monitoring (2009-2011) carried out by the Federal Institute for Research on Building, Urban Affairs and Spatial Development (BBSR), case studies and expert interviews in 12 selected locations in the four German metropolitan areas of Kassel, Leipzig, the Ruhr and Hamburg are used by the authors to develop a conceptual framework that allows a spatially and temporally differentiated view on suburban spaces to be taken. The paper demonstrates the ways in which different lifecycles in suburbanisation processes lead to different strategies for the redevelopment of suburbia.

We are convinced that the papers in this special issue will further advance the current debate about the structure and potential of suburban spaces in Germany and Europe and wish you all stimulating reading. 